\title{
RESEARCH
}

Open Access

\section{Potential prophylactic effect of chemical chaperones for alleviation of endoplasmic reticulum stress in experimental diabetic cataract}

Amany Abdel-Ghaffar ${ }^{* *}$, Ghada G. Elhossary², Atef M. Mahmoud', Amany H. M. Elshazly² (D, Olfat A. Hassanin ${ }^{3}$, Anisa Saleh ${ }^{4}$, Sahar M. Mansour ${ }^{4}$, Fatma G. Metwally ${ }^{4}$, Laila K. Hanafy ${ }^{4}$, Sawsan H. Karam ${ }^{4}$, Hager E. Amer ${ }^{1}$, Nadia A. Samy ${ }^{1}$ and Ahmed Mostafa Ata ${ }^{1}$

\begin{abstract}
Background: Imbalance between protein synthesis and endoplasmic reticulum (ER) capacity to modify and fold proteins lead to the accumulation of unfolded proteins resulting in ER stress and apoptosis. Chaperones are major defense molecules assisting in protein folding, transport, and cellular signaling. ER stress plays a major role in the pathogenesis of diabetes mellitus (DM) and its complications, e.g., diabetic cataract. In the present investigation, the chemical chaperones 4-phenylbutyric acid (4-PBA), tauroursodeoxycholic acid (TUDCA), and trimethylamine N-oxide (TMAO) are used as potential therapeutic agents for alleviation of DM-induced ER stress and diabetic cataract in rats. Animals are subjected to biochemical analysis of blood and lenses for ER stress and apoptosis markers. Moreover, ophthalmologic examination and histopathologic examination of the lenses were done to confirm the results.

Results: Both ophthalmic and lens histopathologic examination revealed that treatment with 4-PBA and TUDCA retarded the occurrence of cataract markedly. Whereas, treatment with TMAO caused a partial improvement of cataract. Moreover, biochemical tests showed that both 4-PBA and TUDCA produced a remarkable improvement in the ER marker levels (VEGF and caspase-12), GSH, MDA, TAC levels in lens tissues. On the other hand, TMAO had no significant effect on these parameters. However, Western blot analysis of lens homogenates showed a suppressed expression of GRP78 and CHOP after treatment with 4-PBA, TUDCA, and TMAO. Moreover, all treated groups showed a significant improvement of lens soluble proteins and their UV spectra absorption. A significant improvement in fasting blood sugar, GSH, serum MDA, and TAC were noted in all treated groups. 4-PBA produced a significant decrease in insulin resistance, whereas TUDCA and TMAO showed insignificant change.

Conclusion: The present research found that the tested chaperones could be used as a therapeutic approach for clinically relevant disorders featuring ER dysfunction such as DM and for reducing its complications in the eye mainly cataract. However, TUDCA and 4-PBA were found to have a more potential efficacy in reducing most of the tested parameters as compared to TMAO.
\end{abstract}

Keywords: ER stress, Diabetes mellitus, Cataract, Chaperones, TUDCA, 4-PBA, TMAO

\footnotetext{
* Correspondence: amany300@hotmail.com

'Department of Biochemistry, Research Institute of Ophthalmology, 2 Al

Ahram Street, 12111 Giza, Egypt

Full list of author information is available at the end of the article
} 


\section{Introduction}

The endoplasmic reticulum (ER) is a central multifunctional organelle entrusted with post-translational modification, folding and maturation of proteins, lipid synthesis, and calcium storage (Walter and Johnson 1994). Hydroxylation, lipidation, oligomerization, disulphide oxidation, and $\mathrm{N}$-linked glycosylation are common modification to the majority of secreted proteins in the ER (Rajan et al. 2007). Factors including temperature, salt concentration, water, lipid bilayer, and chaperones play an important role in proper protein folding (Browm and Naidoo 2012). The ER lumen has the highest $\mathrm{Ca}^{2+}$ concentration within the cell and is densely populated with calcium-dependent chaperones such as glucose-regulated protein $78 \mathrm{kDa}$ (Bip/ Grp78), Grp94, and calreticulin (Anelli and Sitia 2008).

The sensitive folding environment in the ER can be disturbed by both pathological insults such as toxins, viral infections, inflammatory cytokines and excessive mutant protein expression, and by physiological processes such as aging and the large biosynthetic load as high insulin production in beta cells in response to food uptake (Fonseca et al. 2009). Imbalance between protein synthesis and ER capacity to modify and fold proteins can lead to the accumulation of unfolded proteins in the ER lumen. This condition is called ER stress (Balasubramanyam et al. 2010). However, ER triggers an adaptive mechanism termed the ER stress response or the unfolded protein response (UPR) to reduce overall protein synthesis speed by upregulating ER molecular chaperones recovering homeostasis (Kapoor and Sanyal 2009).

Transduction of the UPR signal across the ER membrane is carried out by three transmembrane proteins; inositol-requiring protein-1 (IRE-1), protein kinase RNA (PKR)-like ER kinase (PERK), and activating transcription factor-6 (ATF6) (Hu et al. 2012).

On excessive exposure to ER stress, apoptosis can occur through different mechanisms. The first involves transcriptional induction of CHOP gene (CCAAT/ enhancer-binding protein homologous protein) mediated by the three proteins IRE-1, PERK, and ATF6 (Zinszner et al. 1998). Another mechanism is through the recruitment of TNF-receptor-associated factor 2 (TRAF2) by IRE1 and the activation of apoptosis-signaling-kinase 1 (ASK1) followed by c-Jun N-terminal kinase (JNK) activation and cellular death (Urano et al. 2000). Activation of caspase-12 initiates also a cascade terminating in apoptosis (Nakagawa et al. 2000). Moreover, prolonged ER stress can result in cell necrosis associated with autophagy (Ishida and Nagata 2009).

Upregulation of the chaperone capacity is considered one of the central ER stress defense strategies and homeostasis of the cell. They assist in protein folding, assembly of the macromolecular complexes, protein transport, and cellular signaling (Ullman et al.
2008). During stress conditions, their expression is highly regulated. If the chaperone activity is dysregulated, the unfolded, misfolded, or aggregated proteins are either targeted to degradation pathways or accumulate in cells, leading to impairment of function and eventually contributing to various diseases (Engin and Hotamisligil 2010). In addition, chaperones can function as signal transduction molecules and play a role in histone-mediated chromatin remodeling (Ransom et al. 2010).

Chaperons are classified into the molecular, pharmacological, and chemical chaperones. Molecular chaperones include nucleoplasmins, chaperonins, and heat shock proteins (Hsp) (Oikawa et al. 2007). Pharmacological chaperones are small molecular drugs that enter the cell and act by restoration of the folding ability of the mutant protein (Engin and Hotamisligil 2010). Chemical chaperones are also small molecules that equilibrate cellular osmotic pressure, so they are termed osmolytes. They stabilize the misfolded proteins, reduce their aggregation, and alter the activity of endogenous molecular chaperones. Examples include carbohydrates (glycerol, sorbitol, inositol), amino acids, and derivatives and methylamines (Welch and Brown 1996).

Modifying chaperones or identifying chemical chaperones that can modulate or mimic the endogenous chaperones activity could become an important therapeutic approach for clinically relevant disorders featuring ER dysfunction such as diabetes mellitus (DM) and its complications in different tissues (Lipson et al. 2006).

Worldwide, more than 285 million people are affected by diabetes mellitus. DM involves dysfunction of pancreatic $\beta$ cell. Increasing evidence supports that ER stressmediated $\beta$ cell dysfunction and death have a major role in the pathogenesis of both type 1 and type 2 diabetes mellitus. Exposure of $\beta$ cells to inflammatory cytokines induces the production of nitric oxide $(\mathrm{NO})$ which leads to the attenuation of the sarcoendoplasmic reticulum calcium pump by calcium ATPase2b (SERCA2b) and therefore the reduction of calcium in the ER. Calcium depletion leads to severe ER stress and the induction of the pro-apoptotic transcription factor CHOP (Cardozo et al. 2005). The pro-apoptotic transcription factor ATF3, which is induced by pro-inflammatory cytokines and nitric oxide (NO), may also contribute to ER stress-mediated apoptosis in type 1diabetes (Hartman et al. 2004).

Resistance to insulin action in peripheral tissues which is one of the primary presenting features of type 2 diabetes leads to the hyper-production of insulin in the $\beta$ cell which overwhelms the folding capacity of the ER, leading to chronic activation of the UPR followed by $\beta$ cell dysfunction and eventual $\beta$ cell death. Several components of ER stress signaling that could contribute to this $\beta$ cell loss including IRE1-JNK signaling, CHOP, and 
glycogen synthase kinase $3 \beta$ (GSK3 $\beta$ ) (Fonseca et al. 2009; Ozcan et al. 2004).

A frequent ocular complication of DM is cataract which is considered a major cause of visual impairment in diabetic patients. Due to increasing numbers of diabetics worldwide, the incidence of diabetic cataracts steadily rises. Even though cataract surgery is an effective cure, the elucidation of patho-mechanisms to delay or prevent the development of cataract remains a challenge (Pollreisz and Schmidt-Erfurth 2010).

The development of diabetic cataract is linked to intracellular accumulation of sorbitol resulting in osmotic stress which induces apoptosis in lens epithelial cells (LEC) and cataract formation. Osmotic stress induces stress in the ER that may also result from fluctuations of glucose levels initiating an UPR. UPR generates reactive oxygen species (ROS) and causes oxidative stress damage to lens fibers (Ikesugi et al. 2006b). The free radical nitric oxide (NO), another factor elevated in the diabetic lens and in the aqueous humor may lead to an increased peroxynitrite formation, which in turn induces cell damage due to its oxidizing properties.

Furthermore, increased glucose levels in the aqueous humor may induce glycation of lens proteins, a process resulting in the generation of superoxide radicals $\left(\mathrm{O}^{-}{ }_{2}\right)$ and in the formation of advanced glycation end products (AGE) that interact with receptors in the epithelium of the lens and further $\mathrm{O}^{-}{ }_{2}$ and $\mathrm{H}_{2} \mathrm{O}_{2}$ are generated (Pollreisz and Schmidt-Erfurth 2010). In addition to increased levels of free radicals, diabetic lenses show an impaired antioxidant capacity, increasing their susceptibility to oxidative stress. The loss of antioxidants is exacerbated by glycation and inactivation of lens antioxidant enzymes like superoxide dismutases (Pollreisz and Schmidt-Erfurth 2010). Moreover, in lenses of diabetic patients, the expression of calpain and caspase-12 increase significantly with longer duration of diabetes leading to apoptosis of LECs resulting in cataract formation (Ahn et al. 2016).

Administration of chaperones could become an important therapeutic approach for ER dysfunction in diabetes mellitus (DM) and its complications in different tissues (Lipson et al. 2006).

In the present study, three chaperones are of particular interest, namely 4-phenylbutyric acid (4-PBA), tauroursodeoxycholic acid (TUDCA), and trimethylamine $\mathrm{N}$-oxide (TMAO).

4-PBA is an aromatic fatty acid used to treat urea cycle disorders, because its metabolites offer an alternative pathway to the urea cycle to allow excretion of excess nitrogen. 4-PBA is also a histone deacetylase inhibitor and chemical chaperone, leading respectively to research into its use in protein misfolding diseases (Yung et al. 2016; Cheang et al. 2017).
TUDCA is the taurine conjugate of ursodeoxycholic acid (UDCA), a secondary bile acid produced by intestinal bacteria. Several studies have demonstrated that TUDCA serves as an anti-apoptotic agent for a number of diseases including diabetes and obesity (Vang et al. 2014).

As regards the effect of TMAO in alleviating ER stress, it was reported that it attenuated ER stress in streptozotocin diabetic rats when it was administered for 12 weeks (Lupachyk et al. 2013). Also, it partially protected human hepatoma cells palmitate-induced severe ER stress and deleterious UPR signaling (Achard and Laybutt 2012).

In the present investigation, the chemical chaperones 4-PBA, TUDCA, and TMAO are used as potential therapeutic agents for alleviation of ER stress caused by DM in rats. Animals are subjected to biochemical analysis of blood, and lenses for ER stress and apoptosis markers. Moreover, ophthalmologic examination and histopathologic examination of the lenses were done to confirm the results.

\section{Materials and methods Chemicals}

Chemicals used in this study were of high analytical grade. The antibodies against, CHOP, GRP78, and Beta-Actin were purchased from Cell Signaling Technology (USA), LSBIO (Seattle, Washington) and Rockland (Limerick, Ireland) respectively. Finally, secondary anti-rabbit IgG-horse-radish peroxidase polyclonal antibody was purchased from ENZO (USA).

Streptozotocin (STZ) is a glucosamine-nitrosourea which is commonly used to induce experimental diabetes in animals (Szkudelski 2001). It was supplied as a crystalline solid from Cayman chemical (USA).

4-Phenylbutyric acid (4-PBA) was purchased from Acros Organics (Belgium) in the form of white to slightly yellowish crystalline powder.

Taurine conjugate ursodeoxycholic acid (TUDCA) is an ambiphilic bile acid. It is the taurine conjugate form of ursodeoxycholic acid (UDCA). It was purchased from DOP Organic Chemical.

Trimethylamine N-oxide (TMAO) is the organic compound in the class of amine oxides with the formula $\left(\mathrm{CH}_{3}\right)_{3} \mathrm{NO}$. This colorless solid compound is usually encountered as the dihydrate. It was purchased from Sigma-Aldrich Company.

\section{Animals}

The experimental study was carried out on 95 male Wistar rats, weighing $150-180 \mathrm{~g}$ and obtained from the laboratory animal research house, Research Institute of Ophthalmology (RIO). The rats were housed in stainless steel cages with free access to drinking water and food. Animals were maintained under standard conditions of ventilation, temperature $\left(25 \pm 2{ }^{\circ} \mathrm{C}\right)$, humidity $(60-70 \%)$, and light/dark condition $(12 / 12 \mathrm{~h})$. 
Animal care and protocols were in accordance with the guidelines and approval of the Ethical Committee of RIO. The experiment was performed in accordance to the ARVO Statement for the Use of Animals in Ophthalmic and Vision Research. Eyes of animals were examined by using slit lamp (Carl Zeiss) before induction of diabetes and those with any defect of lens or retina were excluded. After a week of adaptive feeding, the rats were randomly divided into a normal control group (NC, $n=15)$ and diabetes induction group $(n=$ $80)$. NC rats were fed a normal control diet "NCD" ( $11 \%$ fat, $20 \%$ protein, and $67 \%$ carbohydrate, as a percentage of total $\mathrm{kcal}$ ), while diabetes induction rats were fed a high-fat diet "HFD" (58\% fat, $25 \%$ protein, and $17 \%$ carbohydrate, as a percentage of total kcal) (Srinivasan et al. 2004).

\section{Induction of diabetes}

After 2 weeks of dietary manipulation, the insulin resistance state was monitored through measuring the glucose and insulin levels in the blood of HFD-fed animals and calculating the homeostasis model assessment of insulin resistance (HOMA-IR). Rats with insulin resistance were injected intraperitoneally with low dose of STZ (35 mg/ $\mathrm{kg}$ body weight, dissolved immediately before use in $0.1 \mathrm{M}$ citrate buffer, $\mathrm{pH} 4.4$ ) after a period of $6 \mathrm{~h}$ fasting (Srinivasan et al. 2005). Control rats were injected with equivalent volumes of the vehicle citrate buffer intraperitoneally. After $72 \mathrm{~h}$, blood glucose was monitored in all rats via glucometer and animals whose blood glucose level exceeded $200 \mathrm{mg} / \mathrm{dl}$ were considered diabetic and included in the study (60 rats out of 80 ).

\section{Experimental design}

Rats were divided into the following groups.

Group I: The normal control group.

The diabetic rats with insulin resistance were subdivided into equal four groups:

Group II: Diabetic model rats were left without treatment.

Group III: Diabetic rats received 4-PBA (D + 4-PBA) in a dose of $1 \mathrm{~g} / \mathrm{kg} /$ day for 12 weeks by gavage (Ozcan et al. 2006).

Group IV: Diabetic rats received TUDCA (D + TUDCA) in a dose of $500 \mathrm{mg} / \mathrm{kg} /$ day for 12 weeks intraperitoneally (Ozcan et al. 2006).

Group V: Diabetic rats received TMAO (D + TMAO) in a dose $110 \mathrm{mg} / \mathrm{kg} /$ day for 12 weeks in drinking water (Lupachyk et al. 2013).

Drugs in groups III, IV, and V were administered starting from induction of diabetes and continued daily for 12 weeks. Fasting blood glucose and body weights were monitored weekly.

\section{Ophthalmological examination}

Eyes of all animals were subjected to ophthalmological examination by the same examiner every week during the experimental period. All pupils were fully dilated with topical instillation of one drop of tropicamide eye drops in each eye, followed by another drop after $10 \mathrm{~min}$. Then, lens examination and photography was done using slit lamp biomicroscopy (Huvitz, HS 5000, Shanghai, China). Lens changes were categorized and graded according to Suryanarayana et al. (2003) as follows:

Stage 0: Normal lens.

Stage 1: Minimal opacity at the center of lens.

Stage 2: Patchy appearance of opacity both in the center and periphery of lens.

Stage 3: Uniform opalescence all over the lens.

Stage 4: Mature cataract with nuclear opacity.

\section{Sample collection}

At the end of the experiment, all rats in the normal control and experimental groups were anesthetized with diethyl ether. Blood was drawn from retero-orbital plexus (inner aspect of eye) using heparinized capillary tubes and divided into three test tubes:

- In the first tube, sodium fluoride and EDTA were added to determine blood glucose level.

- In the second tube, $150 \mu \mathrm{l}$ of acid citrate dextrose were added to determine reduced glutathione.

- The third tube was left to clot and serum was separated by centrifugation at $3000 \mathrm{rpm}$ for 10 min. The serum was used for estimation of malondialdehyde, total antioxidant capacity, and insulin.

After obtaining blood samples, animals were sacrificed and the eyes were enucleated for dissection of lenses. Lenses were cleaned from blood with $0.9 \% \mathrm{NaCl}$ and divided into two categories:

- The first: lenses were weighed and stored at $-70{ }^{\circ} \mathrm{C}$ for biochemical investigation.

- The second: lenses were fixed in glutaraldehyde 4\% for $6 \mathrm{~h}$ for histopathological examination.

\section{Biochemical analysis}

Measurement of fasting blood glucose and serum insulin

Plasma glucose was determined by the method described by Trinder (1969). Serum insulin was determined using DRG Rat Insulin ELISA Kit according to manufacturer's instructions. Homeostasis model assessment-insulin resistance (HOMA-IR) was calculated to measure insulin sensitivity of rats fed the experimental diet by the following 
formula: [Fasting plasma insulin $(\mu \mathrm{g} / \mathrm{L}) \times$ fasting blood glucose $(\mathrm{mg} / \mathrm{dL})] / 22.5$ (Matthews et al. 1985).

\section{Measurement of malondialdehyde}

The extent of lipid peroxidation was monitored through measuring the level of malondialdehyde (MDA) by the method described by Ohkawa et al. (1979).

\section{Measurement of reduced glutathione}

Erythrocyte glutathione (GSH) concentration was determined by the method described by Beutler and Duron 0 and Kefly B M. (1963) and according to the method modified by Xu et al. (1992) in lens homogenate.

\section{Measurement of total antioxidant capacity}

The total antioxidant capacity (TAC) was determined by the method described by Koracevic et al. (2001).

\section{Measurement of lens caspase-12}

Caspase-12 level (marker of endoplasmic reticulum stress and apoptosis) was determined in the soluble fraction of tissue homogenate using a double-sandwich ELISA Kit for rat caspase-12 from My Bio Source (USA) following the manufacturer's instructions. The pre-coated antibody was Rat Caspase-12 monoclonal antibody and the detecting antibody was polyclonal antibody with biotin labeled. The developed color was measured with the micro-plate reader Stat fax 303 plus (USA) at $450 \mathrm{~nm}$. Absorbance readings were converted into concentration values using a standard curve.

\section{Measurement of lens vascular endothelial growth factor}

Levels of vascular endothelial growth factor (VEGF) were quantified in the lens by an ELISA method using a kit from R\&D Systems, MN. The standard solution or the samples were added in a 96-well plate that was pre-coated with a monoclonal antibody. The samples were incubated for $2 \mathrm{~h}$, and after washing the plate the samples were incubated with rat VEGF-conjugate. The developed color was measured with the micro-plate reader Stat fax 303 plus (USA) at $450 \mathrm{~nm}$. Absorbance readings were converted into concentration values using a standard curve.

\section{Western blot analysis}

A weight of $0.2 \mathrm{~g}$ lens was homogenized in $1 \mathrm{ml}$ of ice-cold lysis buffer (Glycerol, Triton $\times 100,5 \mathrm{M} \mathrm{NaCl}$, $1 \mathrm{M}$ HEPES- $\mathrm{NaCl} \mathrm{pH} 7.5,0.5 \mathrm{M}$ EDTA, $0.1 \mathrm{M} \mathrm{MgCl}_{2}$, Protease inhibitor cocktail (ENZO)) to obtain 20\% (w/v) whole tissue homogenate. The homogenate was then centrifuged at $13,000 \mathrm{rpm}$ for $20 \mathrm{~min}$ at $4{ }^{\circ} \mathrm{C}$. The supernatant of the whole cell lysate was aspirated carefully, and the concentration of total protein was determined according to Bradford (1976). Proteins were separated by SDS-PAGE method (Laemmli 1970) with minor modifications (Sambrook et al. 1989).

Proteins separated on SDS-PAGE were transferred onto a nitrocellulose membrane in a Mini Trans-Blot electrophoretic transfer cell (BioRad, USA) according to the method described by Towbin et al. (1979), and incubated with primary antibodies for $2 \mathrm{~h}$ with gentle shaking at room temperature or overnight at $4{ }^{\circ} \mathrm{C}$. The following primary antibodies were used: mouse anti GRP78, rabbit anti $\mathrm{CHOP}$, and rabbit anti-beta actin monoclonal antibody as an inner reference protein and diluted as per the manufacturer's recommendations. Target antigens were reacted with primary antibodies and subsequently secondary antibody, i.e., horseradish peroxidase-conjugated anti-rabbit IgG. Immunoreactive bands were developed using chemiluminescence detection system (GE Healthcare). The proteins band intensity was expressed by Image Studio Lite software from LI-COR, Inc. (Lincoln, NE, USA).

\section{Isolation of soluble and insoluble proteins}

De-capsulated lenses were homogenized in tris-glycine buffer $(\mathrm{pH}$ 7.5). The homogenate was centrifuged at $10,000 \times g$ for $15 \mathrm{~min}$ at $4{ }^{\circ} \mathrm{C}$. The supernatant was collected. The obtained supernatant comprised of the water-soluble lens proteins. Obtained pellet was suspended (1:1) in solution containing $7 \mathrm{M}$ urea and $50 \mathrm{mM}$ Tris- $\mathrm{HCl}$ ( $\mathrm{pH}$ 7.4). The homogenate was centrifuged at $10,000 \times g$ for $15 \mathrm{~min}$. The supernatant was collected and the procedure repeated thrice. The obtained supernatant comprised of the insoluble lens protein.

\section{Measurement of lens protein content}

Protein content was measured in both the soluble and insoluble fractions of lens homogenates by the method of Lowry et al. (1951). The total lens protein content and the ratio of soluble to insoluble protein levels were also calculated.

\section{Ultraviolet spectroscopy of soluble lens protein}

To understand the mechanism of altered soluble protein tertiary structure and conformational changes, the tertiary-structural states was monitored by ultraviolet (UV) spectra. A sample of $0.25 \mathrm{ml}$ of soluble lens protein fraction was aspired using an aspiration syringe and diluted to $1 \mathrm{ml}$ with phosphate buffer solution ( $\mathrm{pH}$ 7.4) in a quartz cuvette. The samples were scanned in the range of $250-320 \mathrm{~nm}$ using a Jasco spectrophotometer (Tokyo, Japan) and the acquired data were analyzed using internal integrated software supplied with the instrument (Paik and Dillon 2000).

\section{Histopathological examination}

Lenses were fixed in glutaraldehyde $4 \%$ for $6 \mathrm{~h}$, and then they were cut into two halves at the equator and left 
overnight in phosphate buffer solution. Finally, they were soaked in Mollifex solution (BHD Company) for 3 weeks in order to decalcify the lenses. The specimens were post fixed in osmium tetroxide and dehydrated in ascending grades of ethanol. The specimens were embedded in araldite CY502 and semi-thin 1- $\mu$ m-thick sections were cut for light microscopy and stained with toluidine blue (Glauret 1965).

\section{Statistical analysis}

Values were expressed as the mean \pm SD. Differences between experimental groups were evaluated by one-way analysis of variance (ANOVA) using the statistical package for social sciences (SPSS) software package for Windows (version 17; Armonk, New York, EUA, IBM Corporation). Differences were considered significant at $P$ value less than 0.05 .

\section{Results}

\section{Ophthalmologic examination}

Lens examination by slit lamp biomicroscopy revealed the different stages of cataract changes in each animal. All animals of control group were of stage 0 with clear appearance of the lens as showed by slit lamp photography (Table 1 and Fig. 1). At the end of the experiment, the untreated diabetic model animals of group 2 showed different stages of cataract formation with the majority of the rat eyes having stage 3 cataract changes $(6.7 \%$ in stage $1,13.3 \%$ in stage $2,53.3 \%$ in stage 3 , and $26.7 \%$ in stage 4). Slit lamp photography showed lens opacity with equatorial vacuoles and granular deposits on the anterior surface in the lens (Table 1 and Fig. 2). Treatment with 4-PBA and TUDCA in groups 3 and 4 respectively caused dramatic improvement as most of the rat eyes were of stage $0(86.7 \%$ in stage 0 and $13.3 \%$ in stage 1 for $4-\mathrm{PBA} ; 80 \%$ in stage 0 and $20 \%$ in stage 1 for TUDCA). Slit lamp photography showed clear lens in most of the animals with disappearance of the vacuoles and deposits that were observed in untreated diabetic model eyes (Table 1 and Figs. 3 and 4). In group 5, treatment with TMAO also caused improvement of cataract as $26.7 \%$ were of stage 0 and $40 \%$ of stage 1 but still $20 \%$ of animals were of stage 3 and $13.3 \%$ of stage 4 . Slit

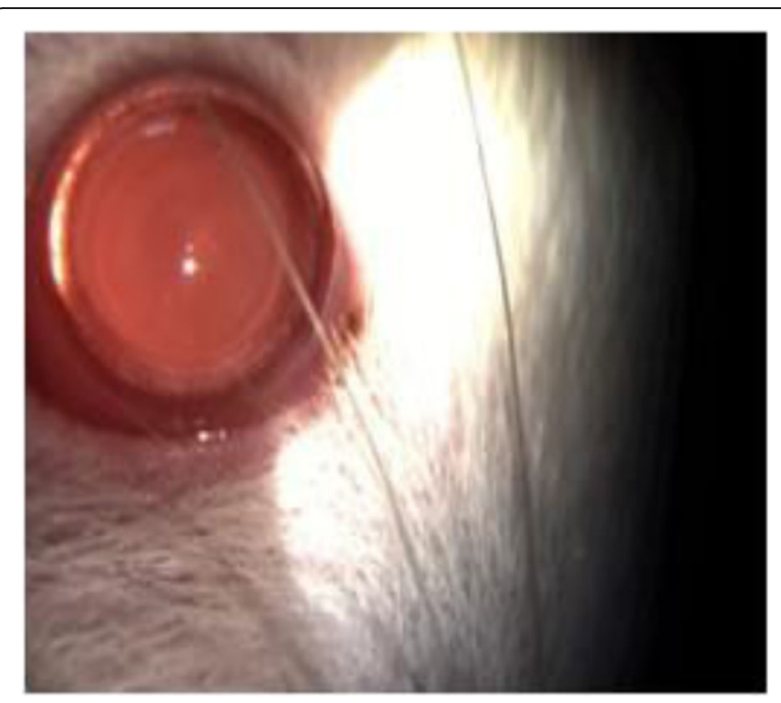

Fig. 1 Slit lamp photography of control group showing clear lens

lamp photography showed lens opacity with water vacuoles inside the lens (Table 1 and Fig. 5).

\section{Biochemical analysis \\ Effect of chemical chaperones administration on diabetic markers}

Fasting blood sugar levels were within the normal range in control group 1 all through the duration of the experiment. Three days after injection of streptozotocin, blood sugar levels were significantly elevated and continued till the end of the 3 months in untreated diabetic model rats of group 2. Treatment with 4-PBA, TUDCA, and TMAO for 3 months (groups 3, 4, and 5 respectively) caused significant decrease of fasting blood sugar levels when compared to untreated model but they were still significantly higher than controls (Table 2).

When compared to controls, induction of diabetes caused a significant decrease in serum insulin levels in untreated diabetic model as well as in the three treated groups which produced slight but insignificant rise in serum insulin levels by the end of the experiment (Table 2).

Insulin resistance as measured by HOMA-IR test was significantly higher in untreated diabetic model when

Table 1 Percentage of different stages of cataract in lenses of each group at the end of the experiment

\begin{tabular}{|c|c|c|c|c|c|}
\hline \multirow[t]{2}{*}{ Experimental groups } & \multicolumn{5}{|c|}{ Stages of cataract } \\
\hline & Stage 0 & Stage 1 & Stage 2 & Stage 3 & Stage 4 \\
\hline Normal control $(n=15)$ & $15(100 \%)$ & 0 & 0 & 0 & 0 \\
\hline Diabetic model $(n=15)$ & 0 & $1(6.7 \%)$ & $2(13.3 \%)$ & $8(53.3 \%)$ & $4(26.7 \%)$ \\
\hline Diabetic model + 4PBA $(n=15)$ & $13(86.7 \%)$ & $2(13.3 \%)$ & 0 & 0 & 0 \\
\hline Diabetic model + TUDCA $(n=15)$ & $12(80 \%)$ & $3(20 \%)$ & 0 & 0 & 0 \\
\hline Diabetic model + TMAO $(n=15)$ & $4(26.7 \%)$ & $6(40 \%)$ & 0 & $3(20 \%)$ & $2(13.3 \%)$ \\
\hline
\end{tabular}




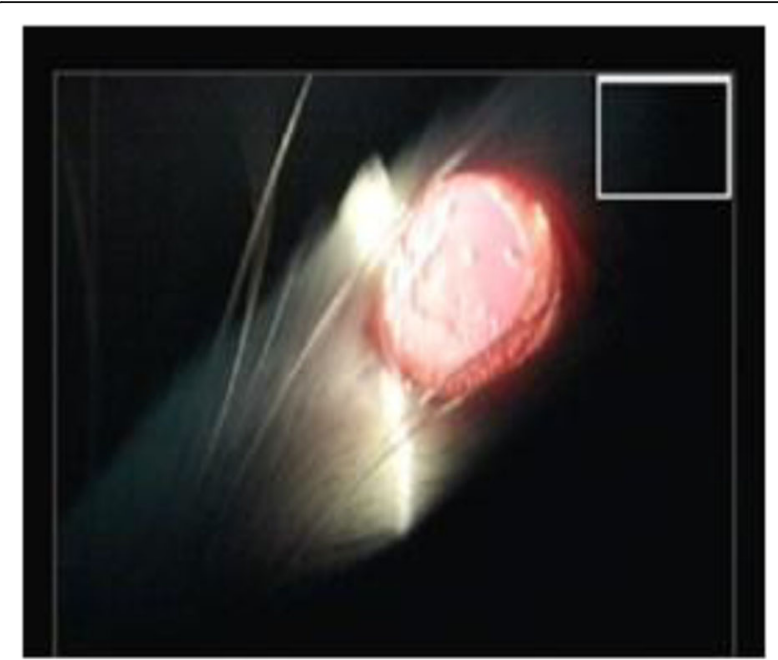

Fig. 2 Slit lamp photography of untreated diabetic model of group 2 showing stage 3 cataract changes with equatorial vacuoles and granular deposits on the anterior surface in the lens

compared with controls of the three treatment groups, only 4-PBA was effective and produced significant decrease in insulin resistance compared with untreated model but the level was still significantly higher than controls. On the other hand, TUDCA and TMAO showed insignificant change in insulin resistance compared with untreated model (Table 2).

\section{Effect of chemical chaperones administration on oxidative stress and antioxidant status}

Markers of oxidative stress and antioxidant status were measured, namely blood GSH, serum MDA, and serum TAC and they were all significantly deteriorated in the untreated model and significantly improved in all treated

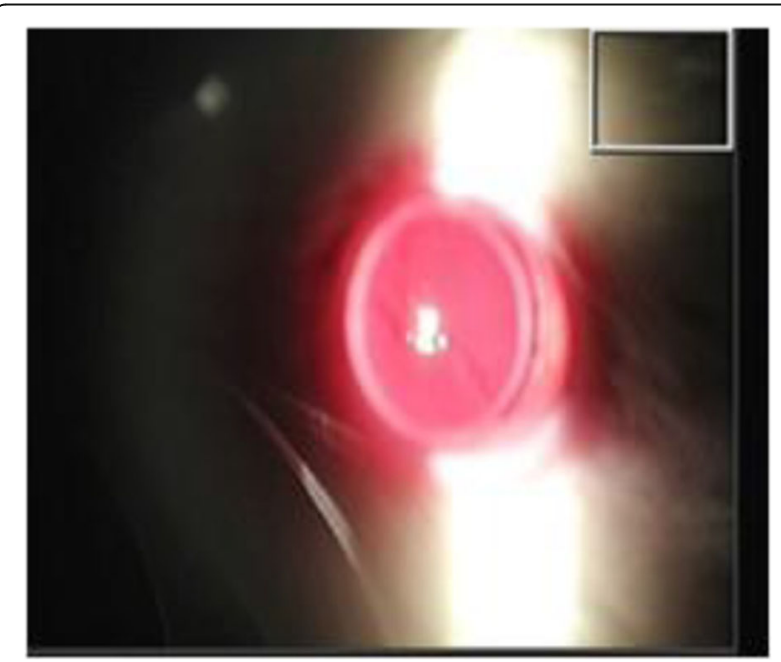

Fig. 3 Slit lamp photography of group 3 (diabetic model treated with 4-PBA) showing clear lens

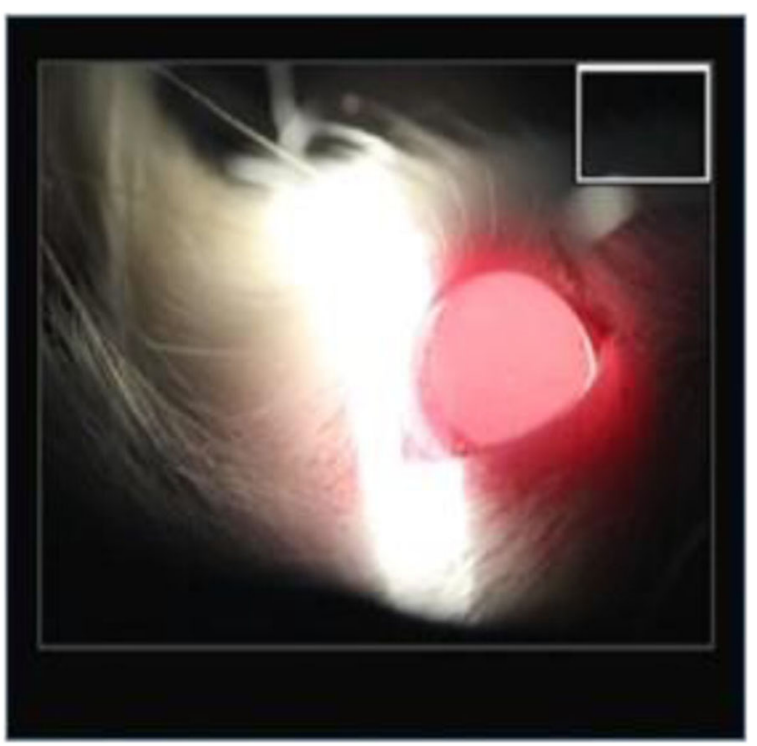

Fig. 4 Slit lamp photography of group 4 (diabetic model treated with TUDCA) showing clear lens

groups. Blood GSH and serum TAC were significantly reduced in the untreated diabetic model compared with controls. Treatment in groups 3,4 , and 5 caused significant elevation in their levels compared with the untreated model but the levels were still significantly lower than controls except for group 3 treated with 4-PBA which produced complete recovery of blood GSH level as it was insignificantly different from controls. Serum MDA concentrations were significantly increased in the untreated model compared with controls and significantly decreased in all treated groups compared with untreated model. However, none of the three drugs produced complete recovery of MDA levels as they were still significantly higher than controls (Table 3).

Examination of the lens tissue biochemically for the oxidant/antioxidant markers GSH, MDA, and TAC showed that they were all significantly deteriorated than controls in untreated diabetic model rats of group 2. Treatment with 4-PBA in group 3 produced significant improvement in all three parameters. Levels of GSH and TAC were significantly elevated than untreated model but were still significantly lower than controls. The level of MDA was significantly decreased than untreated model and insignificantly different from controls. Treatment with TUDCA in group 4 produced significant increase in GSH level, significant decrease in MDA level, and insignificant change in TAC level when compared to untreated model. Glutathione level was still significantly lower than controls while MDA level was more improved as it was insignificantly different from control value. Treatment with TMAO in group 5 did not produce any 


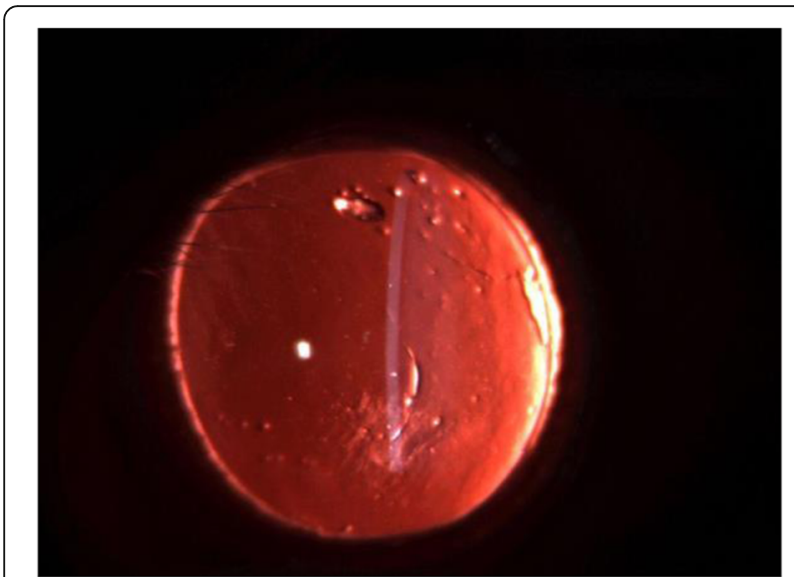

Fig. 5 Slit lamp photography by retro illumination of group 5 (diabetic model treated with TMAO) showing water vacuoles inside the lens

significant change in all three parameters as they were insignificantly different from untreated model and significantly deteriorated from control value (Table 4).

By measuring VEGF and caspase-12 (endoplasmic stress marker) in lens tissue, they were significantly higher than controls in untreated model. In groups 3 and 4, treatment with 4-PBA and TUDCA respectively produced significant depression in VEGF and caspase-12 levels compared with untreated model rats. The levels were insignificantly different from controls except for the effect of TUDCA on VEGF as the level was still significantly higher than

Table 2 Study of plasma fasting blood sugar (FBS), serum insulin, and resistance (HOMA-IR) in control and experimental groups

\begin{tabular}{|c|c|c|c|}
\hline Groups & $\mathrm{FBS} \mathrm{mg} / \mathrm{dl}$ & Insulin $\mu \mathrm{IU} / \mathrm{ml}$ & HOMA-IR \\
\hline \multicolumn{4}{|l|}{ Group 1: control } \\
\hline Range & 7.9-99 & $20-32.5$ & $3.9-7.3$ \\
\hline Mean \pm S.D & $88.6 \pm 7.14$ & $24.84 \pm 4.92$ & $5.37 \pm 1.04$ \\
\hline \multicolumn{4}{|c|}{ Group 2: diabetic model } \\
\hline Range & $200-286$ & $12-22.5$ & $6.2-13.8$ \\
\hline Mean \pm S.D & $231.6 \pm 25.84^{a}$ & $16.57 \pm 3.73^{a}$ & $9.46 \pm 2.33^{a}$ \\
\hline \multicolumn{4}{|c|}{ Group 3: diabetic model + 4PBA } \\
\hline Range & $145-185$ & $11.27-22.5$ & $4-9.7$ \\
\hline Mean \pm S.D & $164.53 \pm 11.71^{a, b}$ & $17.17 \pm 4.06^{\mathrm{a}}$ & $6.9 \pm 1.8^{\mathrm{a}, \mathrm{b}}$ \\
\hline \multicolumn{4}{|c|}{ Group 4: diabetic model + TUDCA } \\
\hline Range & $148-187$ & $12.5-30.1$ & $4.9-13.3$ \\
\hline Mean \pm S.D & $168.53 \pm 14.67^{\mathrm{a}, \mathrm{b}}$ & $19.42 \pm 5.28^{\mathrm{a}}$ & $8.1 \pm 2.45^{\mathrm{a}}$ \\
\hline \multicolumn{4}{|c|}{ Group 5: diabetic model + TMAO } \\
\hline Range & $164-232$ & $11.3-27.5$ & $5.1-12.8$ \\
\hline Mean \pm S.D & $198.53 \pm 24.21^{\mathrm{a}, \mathrm{b}}$ & $18.28 \pm 4.7^{\mathrm{a}}$ & $8.94 \pm 2.55^{\mathrm{a}}$ \\
\hline
\end{tabular}

SD standard deviation. $n=15$

${ }^{\text {a }}$ Significant in comparing with control group at $P<0.05$

${ }^{\mathrm{b}}$ Significant in comparing with diabetic model group at $P<0.05$
Table 3 Blood glutathione (GSH), serum malondialdehyde (MDA), and serum total antioxidant capacity (TAC) in control and experimental groups

\begin{tabular}{|c|c|c|c|}
\hline Groups & GSH mg/dl erythrocyte & MDA nmol/ml & TAC mmol/L \\
\hline \multicolumn{4}{|c|}{ Group 1: control } \\
\hline Range & 75-101.5 & $2.2-4.1$ & $2.1-3.2$ \\
\hline Mean \pm S.D & $85.9 \pm 7.52$ & $3.027 \pm 0.52$ & $2.74 \pm 0.35$ \\
\hline \multicolumn{4}{|c|}{ Group 2: diabetic model } \\
\hline Range & $20-41$ & $8.6-12.8$ & $0.9-1.9$ \\
\hline Mean \pm S.D & $26.53 \pm 6.35^{\mathrm{a}}$ & $10.35 \pm 1.39^{\mathrm{a}}$ & $1.39 \pm 0.27^{\mathrm{a}}$ \\
\hline \multicolumn{4}{|c|}{ Group 3: diabetic model + 4PBA } \\
\hline Range & $72-94$ & $3.8-8.6$ & $2-2.6$ \\
\hline Mean \pm S.D & $84.4 \pm 6^{b}$ & $6.18 \pm 1.53^{\mathrm{a}, \mathrm{b}}$ & $2.28 \pm 0.22^{a, b}$ \\
\hline \multicolumn{4}{|c|}{ Group 4: diabetic model + TUDCA } \\
\hline Range & $55-95$ & $4.8-8.4$ & $1.9-2.9$ \\
\hline Mean $\pm S . D$ & $72.8 \pm 11.9^{\mathrm{a}, \mathrm{b}}$ & $6.34 \pm 1.11^{\mathrm{a}, \mathrm{b}}$ & $2.119 \pm 0.24^{\mathrm{a}, \mathrm{b}}$ \\
\hline \multicolumn{4}{|c|}{ Group 5: diabetic model + TMAO } \\
\hline Range & $46-88$ & $2.8-5.7$ & $2-2.5$ \\
\hline Mean \pm S.D & $58.26 \pm 10.56^{a, b}$ & $4.213 \pm 0.89^{a, b}$ & $2.229 \pm 0.14^{a, b}$ \\
\hline
\end{tabular}

$S D$ standard deviation $n=15$

${ }^{\text {a }}$ Significant in comparing with control group at $P<0.05$

${ }^{\mathrm{b}}$ Significant in comparing with diabetic model group at $P<0.05$

controls. On the other hand, there was no significant effect on both parameters when rats were treated with TMAO in group 5. Levels of VEGF and caspase-12 were insignificantly different from untreated model and significantly higher than controls (Table 5).

\section{Effect of chemical chaperones administration on ER stress- associated protein markers}

Western blot analysis of ER stress-associated protein markers (GRP78 and CHOP) in lens homogenates of control and experimental groups was done. The expression of GRP78 and CHOP in lens of untreated diabetic model rats was increased compared to normal control rats. This increase was suppressed by treatment of diabetic animals with 4-PBA, TUDCA, and TMAO in groups 3, 4, and 5 respectively (Fig. 6).

\section{Effect of chemical chaperones administration on soluble and insoluble lens proteins and its ratio}

The alteration in lens protein profile and insolublization of soluble protein has been considered to be the ultimate factor in lens opacification. Therefore, we analyzed the soluble and insoluble protein content in all groups. A significant decrease in the level of soluble protein fraction and the ratio of soluble/insoluble proteins was recorded in the lenses of diabetic model rats compared to normal group. In addition, diabetic untreated animals showed a significant increase in the level of insoluble proteins compared to normal rats. Treatment of diabetic rats 
Table 4 Mean values \pm S.D. of lens glutathione (GSH), malondialdehyde (MDA), and total antioxidant capacity (TAC) in control and experimental groups

\begin{tabular}{|c|c|c|c|}
\hline Groups & GSH ( $\mu \mathrm{mol} / \mathrm{g}$ tissue) & MDA (nmol/g tissue) & TAC ( $\mu \mathrm{mol} / \mathrm{g}$ tissue) \\
\hline \multicolumn{4}{|l|}{ Group 1: control } \\
\hline Range & $4.68-8.95$ & $5.76-7.21$ & $0.61-2.61$ \\
\hline Mean \pm S.D & $7.08 \pm 1.73$ & $6.23 \pm 0.62$ & $1.37 \pm 0.77$ \\
\hline \multicolumn{4}{|c|}{ Group 2: diabetic model } \\
\hline Range & $0.89-2.8$ & $10.81-18.75$ & $0.11-0.36$ \\
\hline Mean \pm S.D & $1.7 \pm 0.74^{\mathrm{a}}$ & $15.71 \pm 3.2^{\mathrm{a}}$ & $0.18 \pm 0.09^{a}$ \\
\hline \multicolumn{4}{|c|}{ Group 3: diabetic model + 4PBA } \\
\hline Range & $1.83-7.53$ & $5.76-9.61$ & $0.2-1.55$ \\
\hline Mean \pm S.D & $4.52 \pm 1.97^{\mathrm{a}, \mathrm{b}}$ & $7.68 \pm 1.9^{b}$ & $0.77 \pm 0.44^{a, b}$ \\
\hline \multicolumn{4}{|c|}{ Group 4: diabetic model + TUDCA } \\
\hline Range & $2.3-7.53$ & $6.73-10.81$ & $0.06-0.73$ \\
\hline Mean \pm S.D & $4.85 \pm 1.87^{\mathrm{a}, \mathrm{b}}$ & $8.45 \pm 1.7^{b}$ & $0.54 \pm 0.25^{a}$ \\
\hline \multicolumn{4}{|c|}{ Group 5: diabetic model + TMAO } \\
\hline Range & $0.89-4.68$ & $8.41-17.3$ & $0.05-0.36$ \\
\hline Mean \pm S.D & $2.31 \pm 1.33^{\mathrm{a}}$ & $13.3 \pm 3.5^{\mathrm{a}}$ & $0.19 \pm 0.11^{a}$ \\
\hline
\end{tabular}

SD standard deviation $n=15$

${ }^{a}$ Significant in comparing with control group at $P<0.05$

${ }^{b}$ Significant in comparing with diabetic model group at $P<0.05$

with 4-PBA, TUDCA, and TMAO in groups 3 , 4, and 5 respectively significantly reduced these changes. The ability of 4-PBA and TUDCA to improve the decrease in soluble /insoluble ratio of lens protein was remarkable (Fig. 7).

Table 5 Lens vascular endothelial growth factor (VEGF) and caspase-12 in control and experimental groups

\begin{tabular}{|c|c|c|}
\hline Groups & VEGF (pg/mg protein) & Caspase-12 (ng/mg protein) \\
\hline \multicolumn{3}{|l|}{ Group 1: Control } \\
\hline Range & $0.38-1.6$ & $0.07-0.21$ \\
\hline Mean \pm S.D & $0.87 \pm 0.55$ & $0.15 \pm 0.06$ \\
\hline \multicolumn{3}{|c|}{ Group 2: diabetic model } \\
\hline Range & $1.9-3.4$ & $0.3-0.81$ \\
\hline Mean $\pm S . D$ & $2.81 \pm 0.64^{\mathrm{a}}$ & $0.53 \pm 0.19^{a}$ \\
\hline \multicolumn{3}{|c|}{ Group 3: diabetic model + 4PBA } \\
\hline Range & $0.5-2.7$ & $0.07-0.23$ \\
\hline Mean \pm S.D & $1.3 \pm 0.87^{b}$ & $0.12 \pm 0.06^{b}$ \\
\hline \multicolumn{3}{|c|}{ Group 4: diabetic model + TUDCA } \\
\hline Range & $1.25-2$ & $0.19-0.36$ \\
\hline Mean \pm S.D & $1.73 \pm 0.27^{\mathrm{a}, \mathrm{b}}$ & $0.26 \pm 0.08^{b}$ \\
\hline \multicolumn{3}{|c|}{ Group 5: diabetic model + TMAO } \\
\hline Range & $1-3$ & $0.25-0.75$ \\
\hline Mean \pm S.D & $2 \pm 0.95^{\mathrm{a}}$ & $0.41 \pm 0.17^{\mathrm{a}}$ \\
\hline
\end{tabular}

SD standard deviation $n=15$

${ }^{\text {a }}$ Significant in comparing with control group at $P<0.05$

${ }^{b}$ Significant in comparing with diabetic model group at $P<0.05$

\section{Effect of chemical chaperones administration on ultraviolet} spectroscopy of lens crystallins

To explore the altered tertiary structure and conformational changes of lens crystallins, the tertiary structure of soluble lens proteins was investigated by ultraviolet (UV) spectra in all studied groups. UV absorption around $280 \mathrm{~nm}$ showed a sharp decrease of intensity of soluble lens proteins in diabetic untreated rats compared to normal controls suggesting conformational changes at the tertiary structural level. Treatment of diabetic rats with 4-PBA, TUDCA, or TMAO greatly reduced changes in the tertiary structural level of soluble lens proteins manifested by absorption spectra more or less similar to that obtained for normal lenses (Fig. 8).

\section{Effect of chemical chaperones administration on lens histopathological changes}

Lens histopathologic examination was performed by the light microscope. Examination of the lens of control albino rats of group 1 showed the normal appearance of the lens capsule $(C)$, lens epithelium $(E)$, and lens fiber cells (F) (Fig. 9). In the untreated diabetic rats of group 2 , the lens capsule was thickened with decreased mitotic figures of lens epithelium. Plenty of vacuoles were observed in the lens fiber cells (Fig. 10). Treatment of diabetic animals with 4-PBA caused improvement of the histopathologic picture with almost normal appearance of the lens except for the presence of thickened lens capsule (Fig. 11). Treatment of diabetic animals with TUDCA also caused improvement of the histopathologic 


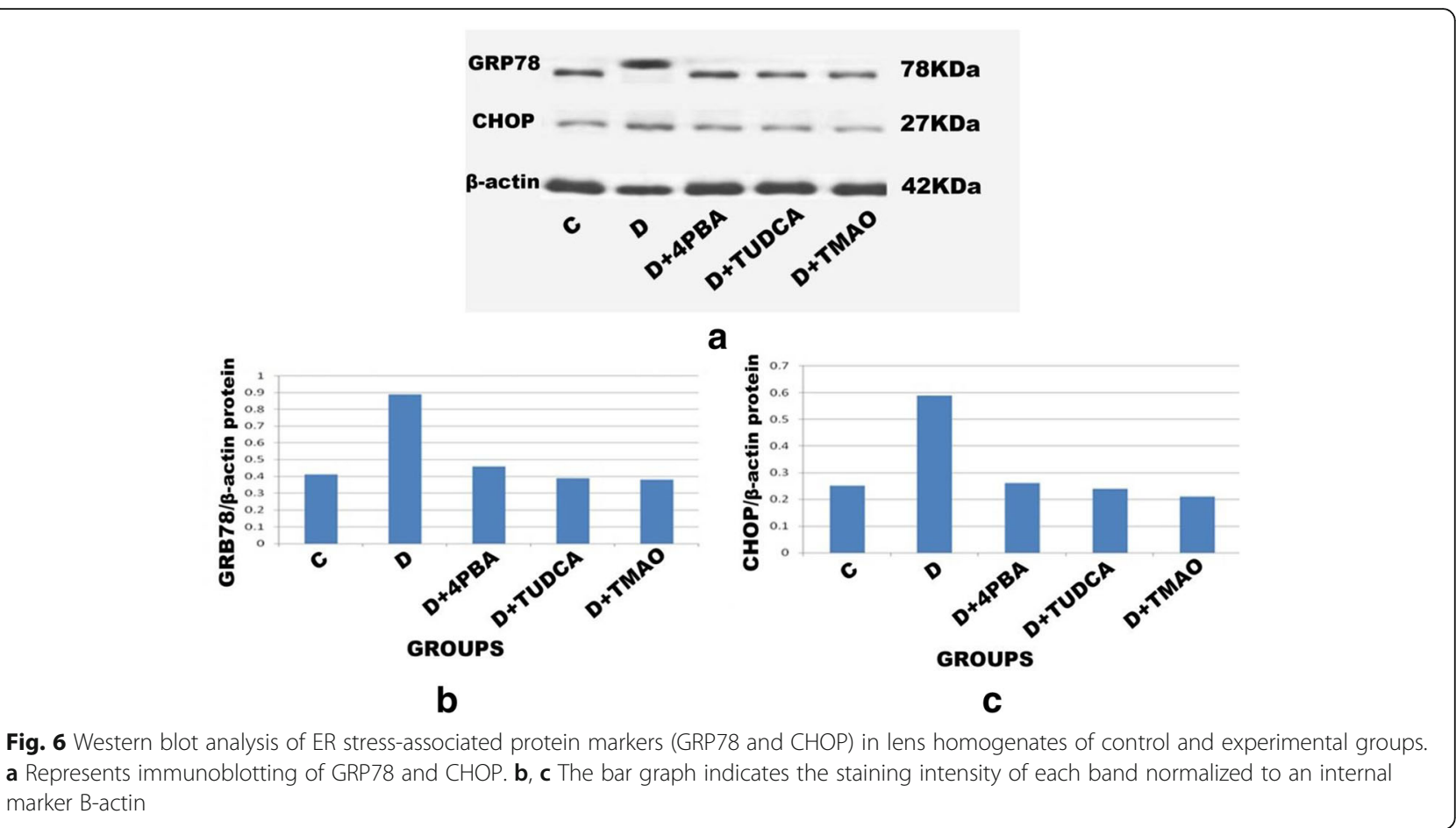

picture as the lens was almost devoid of pathological changes (Fig. 12). On the other hand, treatment of diabetic rats with TMAO caused much less improvement of the histopathologic picture of the lens. There was loss of mitotic figures of lens epithelium, and discontinuity of lens capsule with severe vacuolar changes of lens fiber cells (Fig. 13).

\section{Discussion}

Many studies have greatly increased our knowledge concerning the association between diabetes and cataract formation and have defined many risk factors for the development of cataract. This study aims to spot a light on the role of endoplasmic reticulum (ER) stress in the pathogenesis of diabetic cataract. In addition, the chemical chaperones 4-PBA, TUDCA, and TMAO are used as potential therapeutic agents for alleviation of ER stress and cataract caused by DM in experimental animals (Lipson et al. 2006).

In the present work, insulin resistance was induced in rats by high-fat diet administration for 2 weeks then rats with insulin resistance were injected STZ intraperitoneally to induce a diabetic animal model. Slit lamp biomicroscopy at the end of experiment revealed that untreated
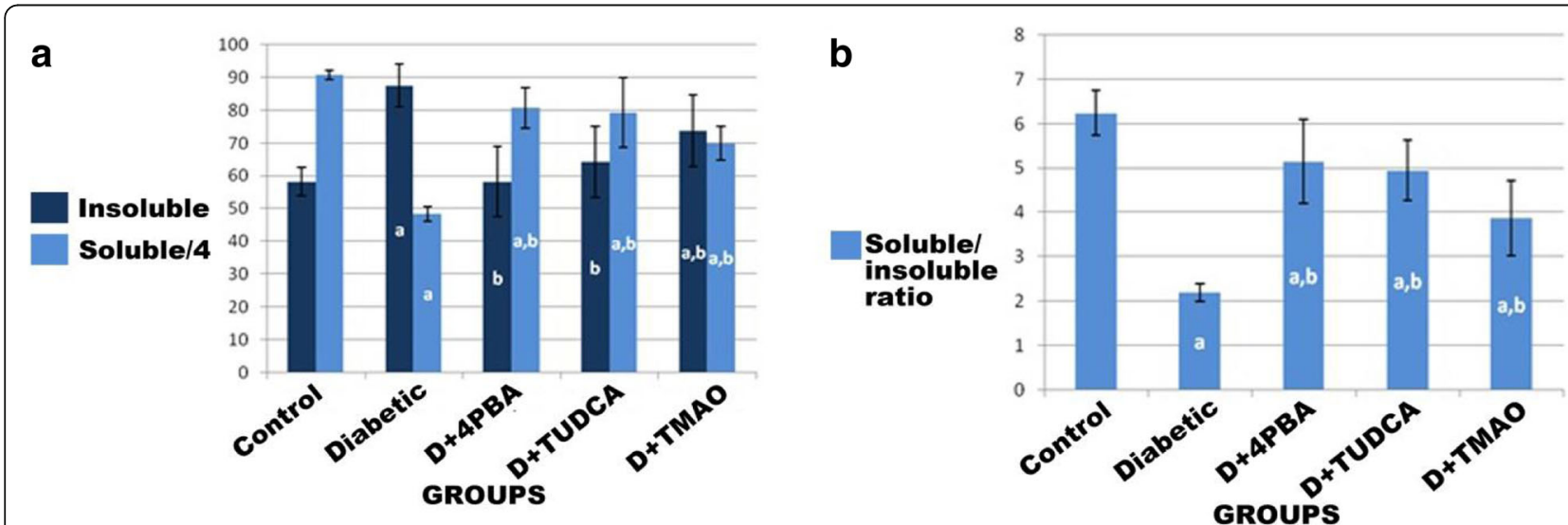

Fig. 7 Mean levels of insoluble and soluble lens proteins in control and experimental groups. a Comparison of soluble and insoluble lens protein. b Soluble/insoluble ratio of lens proteins. a $P<0.05$ significant in comparing with control group. b $P<0.05$ significant in comparing with diabetic model group 


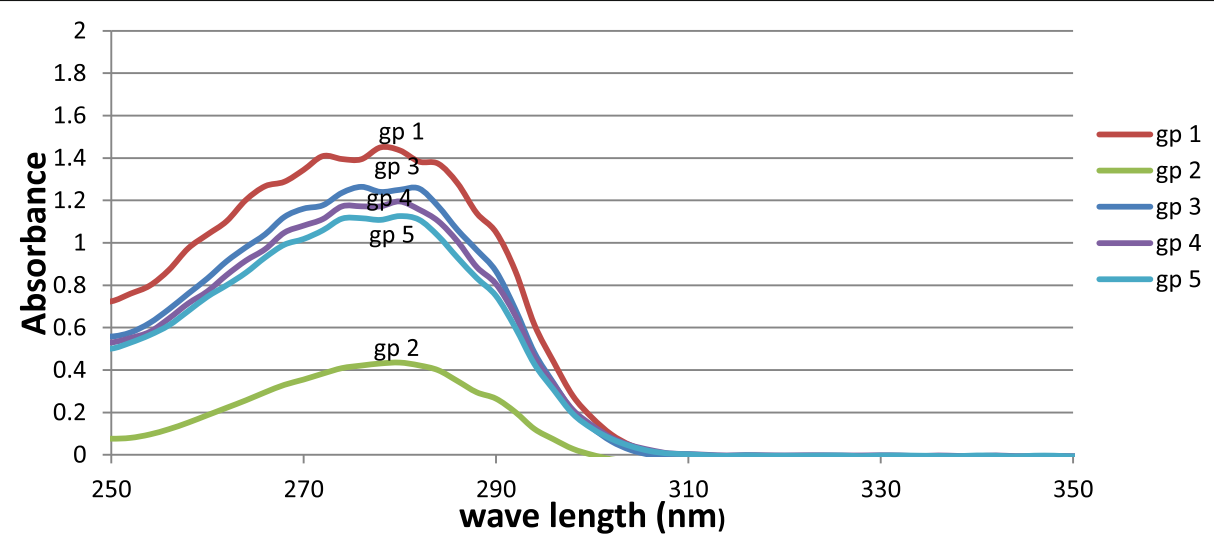

Fig. 8 Ultraviolet absorption spectra of soluble lens proteins in control and experimental groups. gp1: control, gp2: diabetic model, gp3: diabetic model + 4-PBA, gp4: diabetic model + TUDCA, and gp5: diabetic model + TMAO

diabetic model animals showed different stages of cataract formation mainly third stage of cataract. Treatment with 4-PBA and TUDCA retarded the occurrence of cataract markedly as most of the rat eyes were of stage 0 . Whereas treatment with TMAO caused a partial improvement of cataract as only $26.7 \%$ of animals were of stage 0 and the rest of animals showed different stages of cataract.

Lens histopathologic examination confirmed the clinical findings in which treatment of diabetic animals with 4-PBA and TUDCA caused more improvement of the histopathologic picture than TMAO.

The findings of the current work run in parallel with the study of Mulhern et al. (2007) who reported that cellular osmolytes including 4-PBA, TMAO, and TUDCA rescued cultured human LECs which were subjected to ER stressors. Moreover, when they were administered either orally or by injection into galactosemic rats, a

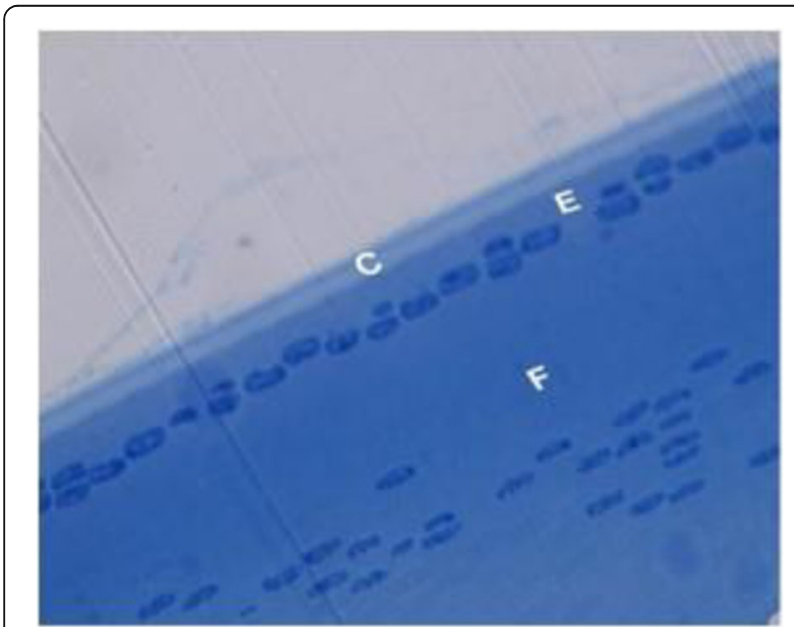

Fig. 9 Light micrograph of rat control lens at the equator showing capsule (C), lens epithelium (E), and lens fiber cells (F) (toluidine blue $\times 500)$ significant reduction in lens epithelial cell death and partial delay in cataract formation was noticed.

Current work examination of the lens tissue biochemically for GSH, MDA, and TAC levels showed that treatment with 4-PBA produced a significant improvement in all three parameters. Treatment with TUDCA produced a significant improvement in GSH and MDA levels and insignificant change in TAC level when compared to untreated model. Whereas treatment with TMAO did not produce any significant change in all three parameters.

Similarly, both 4-PBA and TUDCA produced a significant depression in the endoplasmic stress markers levels (VEGF and caspase-12) in lens tissues when compared to untreated model rats. On the other hand, there was no significant effect on both parameters when rats were treated with TMAO.

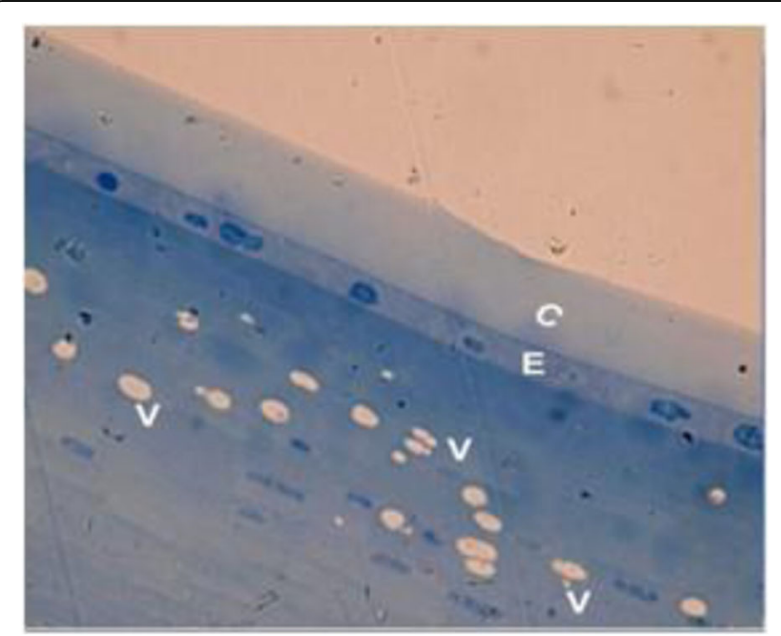

Fig. 10 Light micrograph of rat lens of diabetic model (group 2) showing thickened lens capsule $(C)$, decreased mitotic figures of lens epithelium (E), and plenty of vacuoles $(V$ ) of lens fiber cells (Toluidine blue $\times 500$ ) 


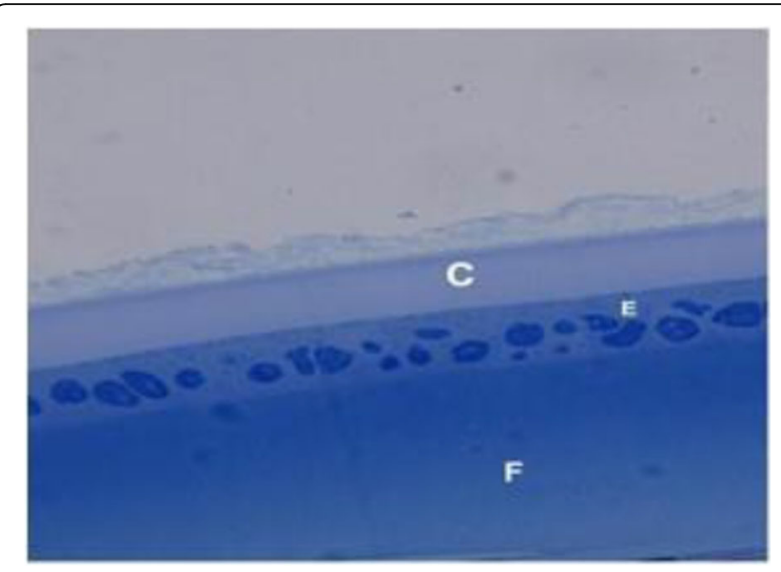

Fig. 11 Light micrograph of rat lens of diabetic model treated with 4-PBA (group 3) showing intact lens epithelium (E) and lens fiber cells (F). However, the lens capsule is still thickened (C) (Toluidine blue $\times 500)$

However, Western blot analysis of lens homogenates of diabetic model rats showed that the increased expression of GRP78 and CHOP in untreated models was suppressed by treatment of diabetic animals with 4-PBA, TUDCA, and TMAO. On excessive exposure to stress as in DM, apoptosis can occur through different mechanisms. The main one involves transcriptional induction of $\mathrm{CHOP}$ gene. Under normal conditions, CHOP is barely detected but during ER stress, it is strongly induced and promotes apoptosis (Zinszner et al. 1998).

Our results are supported by the work of Kawasaki et al. (2012). They treated mice fed a high-fat diet with TUDCA or 4-PBA and noted a significant downregulation of the gene expression levels of ER stress markers and inflammatory cytokines. The study of Achard and

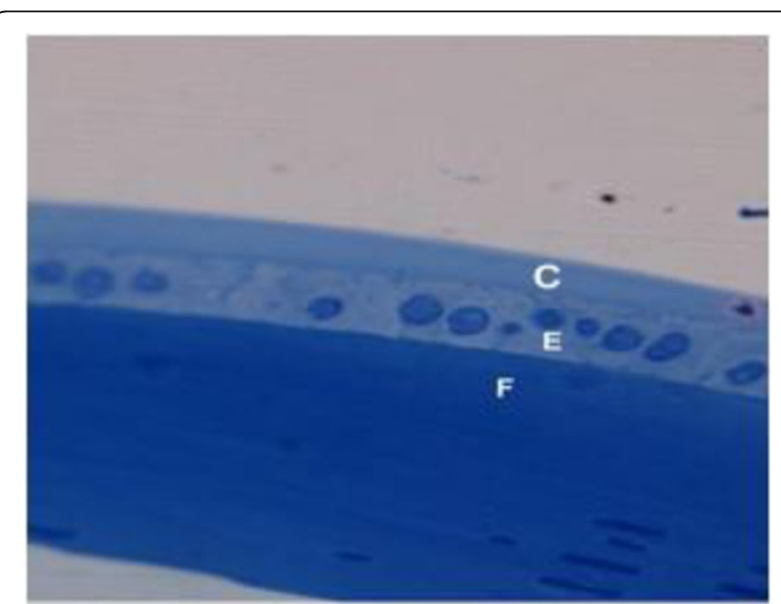

Fig. 12 Light micrograph of rat lens of diabetic model treated with TUDCA (group 4) showing lens capsule (C), epithelium (E), and fibers (F) almost devoid of pathological changes (Toluidine blue $\times 500$ )

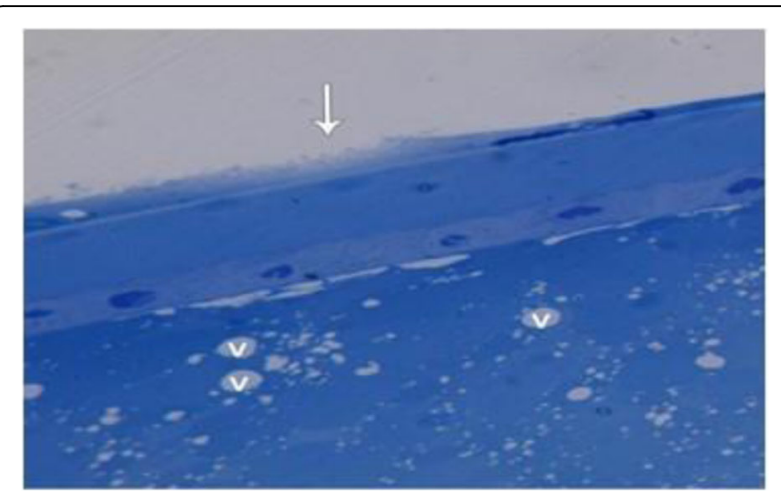

Fig. 13 Light micrograph of rat lens of diabetic model treated with TMAO (group 5) showing discontinuity of lens capsule (arrow), and loss of mitotic figures of lens epithelium with severe vacuolar $(V)$ changes of lens fiber cells (Toluidine blue $\times 500$ )

Laybutt (2012) also has noted the attenuation of ER stress markers by TUDCA administration to human hepatoma cells.

The alteration in lens proteins profile and insolublization of soluble proteins has been considered to be the ultimate factor in lens opacification. Currently, a significant decrease in the level of soluble protein fraction and an increase in the insoluble proteins was recorded in the lenses of diabetic model rats. Treatment with 4-PBA, TUDCA, and TMAO significantly reduced these changes. That was also supported by measuring UV spectra absorption of soluble lens proteins. It showed that the sharp decrease of intensity (indicating tertiary structure and conformational changes) observed in diabetic untreated rats was greatly reduced by treatment of diabetic rats with 4-PBA, TUDCA, or TMAO.

The current findings are confirmed with the study of Gong et al. (2010) who reported that in vitro treatment of lens cells with 4-PBA reduced the defective phenotype of mutant gamma D-crystallin and rescued the affected cells from apoptosis. Gamma D-crystallin is the major structural lens protein and its mutations results in congenital cataract formation (Gong et al. 2010).

Also, TMAO was found to be able to reduce the aggregation of mutant alpha crystallins in human lens epithelial cells, alleviate ER stress, and rescue the affected cells from apoptosis (Gong et al. 2009). Moreover, TUDCA was reported to protect the chaperone activity of $\alpha$-crystallins in human lens in vitro (Song et al. 2011).

Later, other tissues in diabetic mice were studied in which TUDCA reduced the increase in ER stress marker expression (CHOP, ATF4, ATF6, and phosphorylated-eIF2 $\alpha$ ) induced by diabetes in heart and mesenteric resistance arteries (Galán et al. 2012). Also, in vitro TUDCA was able to ameliorate palmitate-induced impairment of vasodilatory response 
to insulin in intact vessels isolated from high-fat fed mice (Kim et al. 2015).

More recently, Cheang et al. (2017) have reported that oral administration of TUDCA to diabetic mice was found to decrease ER stress and to protect against endothelial dysfunction. In addition, another study by Battson et al. (2017) has reported that acute incubation and chronic administration of TUDCA improved endothelium-dependent dilation in mesenteric arteries of type 2 diabetic mice. Chronic TUDCA administration also reduced arterial stiffness and was associated with reductions in ER stress markers in aortic and perivascular adipose tissue.

In the present work, induction of diabetes caused a significant decrease in serum insulin levels in untreated diabetic model as well as in the three treated groups which produced slight but insignificant rise in serum insulin levels by the end of the experiment. Insulin resistance as measured by HOMA-IR test was significantly higher in untreated diabetic model when compared with control of the three treatment groups. 4-PBA was effective and produced a significant decrease in insulin resistance compared with the untreated model but the level was still significantly higher than controls. On the other hand, TUDCA and TMAO showed insignificant changes in insulin resistance compared with untreated model. However, treatment of diabetic rats with the three tested drugs caused a significant decrease in fasting blood sugar levels when compared to untreated model but they were still significantly higher than controls. These findings are parallel to the study of Kars et al. (2010) who treated obese patients with TUDCA for 4 weeks and noted a significant increase in hepatic and muscle insulin sensitivity with a significant increase in muscle insulin signaling which reflects an improved insulin resistance. Moreover, it was found that administration of TUDCA at the prediabetic stage resulted in a marked reduction of diabetes incidence in two different mouse models of type1 diabetes (Engin et al. 2013). Later, Zhang et al. (2016) treated diabetic mice with intraperitoneal TUDCA and noted a significant reduction of blood glucose level with a significant decreased expression of ER stress markers along with decreases in ER stress-associated apoptotic markers.

Blood GSH, serum MDA, and TAC were significantly improved in all present treated groups. It is to be noted that 4-PBA produced complete recovery of blood GSH level. However, none of the three testes drugs produced complete recovery of MDA levels as they were still significantly higher than controls.

Many studies have spotted a light on the therapeutic potential of the tested chaperons. 4-PBA was effective in reducing phosphorylation of eIF $2 \alpha$ which is one of the ER stress markers in placental samples obtained from women suffering from gestational diabetes (Yung et al. 2016). It protected also against endothelial dysfunction in diabetic mice by decreasing ER stress (Cheang et al. 2017). As regards TUDCA, it is a potent inhibitor of apoptosis, in part by interfering with the upstream mitochondrial pathway of cell death, inhibiting oxygen-radical production, reducing ER stress, and stabilizing the UPR (Vang et al. 2014).

Concerning TMAO, it is a small molecule that equilibrate cellular osmotic pressure. It has been suggested that it stabilizes the misfolded proteins, reduce their aggregation, and alter the activity of endogenous molecular chaperones (Welch and Brown 1996). In human trabecular meshwork cells, it facilitated the folding and secretion of mutant myocilin, reduced its distribution in the ER, alleviated ER stress, and rescued cells from apoptosis (Jia et al. 2009). Furthermore, this osmolyte was able to attenuate ER stress, peripheral nerve dysfunction, and intraepidermal nerve fiber loss with inhibition of sciatic nerve and spinal cord oxidative-nitrative stress in streptozotocin diabetic rats (Lupachyk et al. 2013).

\section{Conclusions}

In summary, we established the effective role of the tested chaperones to be used as a therapeutic approach for clinically relevant disorders featuring ER dysfunction such as diabetes mellitus (DM). In addition, the ability of these compounds to decrease the ocular diabetic complications mainly cataract was noticed. Our results had verified (TUDCA) and (4-PBA) were found to have a more potential efficacy in reducing most of the tested parameters as compared to (TMAO). However, further investigations both on animals and humans are needed to spot more lights on the roles, efficacy, and potential side effects of chaperones on ER stress-related diseases.

\section{Abbreviations}

4-PBA: 4-Phenylbutyric acid; ASK1: Apoptosis-signaling-kinase 1; ATF3: Apoptotic transcription factor; ATF6: Activating transcription factor-6; CHOP gene: CCAAT/enhancer-binding protein homologous protein; DM: Diabetes mellitus; ER: Endoplasmic reticulum; GSK3B: Glycogen synthase kinase $3 \beta$; Hsp: Heat shock proteins; IRE-1: Inositol-requiring protein-1; JNK: cJun N-terminal kinase; LEC: Lens epithelial cells; NO: Nitric oxide; PERK: Protein kinase RNA (PKR)-like ER kinase; SERCA2b: Sarcoendoplasmic reticulum pump Ca2+ ATPase2b; TMAO: Trimethylamine N-oxide; TRAF2: TNF-receptor-associated factor 2; TUDCA: Tauroursodeoxycholic acid; UPR: Unfolded protein response

\section{Acknowledgements}

We would like to acknowledge the Research Institute of Ophthalmology for funding our work and providing all requirements of this study.

\section{Individual personal data}

Not applicable.

\section{Funding}

The research was funded by the Research Institute of Ophthalmology.

Availability of data and materials

Data are available upon request from the authors. 


\section{Authors' contributions}

All authors contributed to the study design, laboratory analysis, and writing the manuscript. All authors revised the final manuscript and approved it. AAG carried out the study design, coordination, animal models induction, biochemical studies, writing and drafting the manuscript. GGE shared in the follow-up of experimental animals, biochemical analysis, writing, drafting, and revision of the manuscript. AMM participated in the follow-up and specimens taking from animals, biochemical analysis, and helped to revise the manuscript. AHME participated in the follow up of animals, biochemical analysis, writing, drafting, and revision of the manuscript. OAH performed the ophthalmological examination, and helped to revise the manuscript. AS performed the histopathological examination, and helped in writing, drafting, and revision of the manuscript. SMM participated in histopathological examination, and shared in writing and revision of the manuscript. FGM shared in histopathological examination, writing, and revision of the manuscript. LKH participated in histopathological examination, writing, and revision of the manuscript. SHK shared in histopathological examination, writing, and revision of the manuscript. HEA participated in biochemical analysis, writing, drafting, and revision of the manuscript. NAS participated in the biochemical analysis, writing, drafting, and revision of the manuscript. AMA participated in the follow up of animals, biochemical analysis, performed the statistical analysis, and drafting of the manuscript.

\section{Ethics approval}

The study was approved by the ethical committee of the Research Institute of Ophthalmology.

\section{Consent for publication}

All authors declare that they approved the publication of this research in the Bulletin of National Research Center.

\section{Competing interests}

The authors declare that they have no competing interests.

\section{Publisher's Note}

Springer Nature remains neutral with regard to jurisdictional claims in published maps and institutional affiliations.

\section{Author details}

'Department of Biochemistry, Research Institute of Ophthalmology, 2 Al Ahram Street, 12111 Giza, Egypt. ²Department of Pharmacology, Research Institute of Ophthalmology, Giza, Cairo, Egypt. ${ }^{3}$ Department of Ophthalmology, Research Institute of Ophthalmology, Giza, Cairo, Egypt. ${ }^{4}$ Department of Histology, Research Institute of Ophthalmology, Giza, Cairo, Egypt.

\section{Received: 8 January 2019 Accepted: 12 March 2019}

\section{Published online: 25 April 2019}

\section{References}

Achard CS, Laybutt DR (2012) Lipid-induced endoplasmic reticulum stress in liver cells results in two distinct outcomes: adaptation with enhanced insulin signaling or insulin resistance. Endocrinology 153(5):2164-2177.

Ahn YJ, Kim MS, Chung SK (2016) Calpain and caspase-12 expression in lens epithelial cells of diabetic cataracts. Am J Ophthalmol 167:31-37.

Anelli T, Sitia R (2008) Protein quality control in the early secretory pathway. EMBO J 27(2):315-327.

Balasubramanyam M, Lenin R, Monickaraj F (2010) Endoplasmic reticulum stress in diabetes: new insights of clinical relevance. Indian J Clin Biochem 25(2): $111-118$.

Battson ML, Lee DM, Jarrell DK, Hou S, Ecton KE, Phan AB, Gentile CL (2017) Tauroursodeoxycholic acid reduces arterial stiffness and improves endothelial dysfunction in type 2 diabetic mice. J Vasc Res 54(5):280-287.

Beutler E, Duron O, Kefly BM (1963) Improved method for the determination of blood glutathione. J Lab Clin Med 61:882-888.

Bradford MM (1976) A rapid and sensitive method for the quantitation of microgram quantities of protein utilizing the principle of protein-dye binding. Anal Biochem 72:248-254.

Browm MK, Naidoo N (2012) The endoplasmic reticulum stress response in aging and age-related diseases. Front Physiol 3(263):1-10.
Cardozo AK, Ortis F, Storling J, Feng YM, Rasschaert J, Tonnesen M, Van Eylen F MandrupPoulsen T, Herchuelz A, Eizirik DL (2005) Cytokines downregulate the sarcoendoplasmic reticulum pump Ca2+ ATPase $2 b$ and deplete endoplasmic reticulum $\mathrm{Ca} 2+$, leading to induction of endoplasmic reticulum stress in pancreatic beta-cells. Diabetes 54:452-461.

Cheang WS, Wong WT, Zhao L, Xu J, Wang L, Lau CW, Chen ZY, Ma RC, Xu A, Wang N, Tian XY, Huang Y (2017) PPAR is required for exercise to attenuate endoplasmic reticulum stress and endothelial dysfunction in diabetic mice. Diabetes 66(2):519-528.

Engin F, Hotamisligil GS (2010) Restoring endoplasmic reticulum function by chemical chaperones: an emerging therapeutic approach for metabolic diseases. Diabetes Obes Metab 12(Suppl 2):108-115.

Engin F, Yermalovich A, Nguyen T, Hummasti S, Fu W, Eizirik DL, Mathis D, Hotamisligil GS (2013) Restoration of the unfolded protein response in pancreatic $\beta$ cells protects mice against type 1 diabetes. Sci Transl Med 5(211):1-27.

Fonseca SG, Burcin M, Gromada J, Urano F (2009) Endoplasmic reticulum stress in beta cells and development of diabetes. Curr Opin Pharmacol 9(6):763-770.

Galán M, Kassan M, Choi SK, Partyka M, Trebak M, Henrion D, Matrougui K (2012) A novel role for epidermal growth factor receptor tyrosine kinase and its downstream endoplasmic reticulum stress in cardiac damage and microvascular dysfunction in type 1 diabetes mellitus. Hypertension 60(1):71-80.

Glauret AM (1965) The fixation and embedding of biological specimens in: techniques for electron microscope DH (ed.). Davis Co, Philadelphia, pp $166-212$.

Gong B, Zhang LY, Lam DS, Pang CP, Yam GH (2010) Sodium 4-phenylbutyrate ameliorates the effects of cataract-causing mutant gammaD-crystallin in cultured cells. Mol Vis 16:997-1003.

Gong B, Zhang LY, Pang CP, Lam DS, Yam GH (2009) Trimethylamine N-oxide alleviates the severe aggregation and ER stress caused by G98R alphaAcrystallin. Mol Vis 15:2829-2840.

Hartman MG, Lu D, Kim ML, Kociba GJ, Shukri T, Buteau J, Wang X, Frankel WL, Guttridge D, Prentki M et al (2004) Role for activating transcription factor 3 in stress-induced beta-cell apoptosis. Mol Cell Biol 24:5721-5732.

Hu WK, Liu R, Pei H, Li B (2012) Endoplasmic reticulum stress-related factors protect against diabetic retinopathy. Exp Diabetes Res 10(13):1-11.

Ikesugi K, Yamamoto R, Mulhern ML, Shinohara T (2006) Role of the unfolded protein response (UPR) in cataract formation. Exp Eye Res 83:508-516.

Ishida Y, Nagata K (2009) Autophagy eliminates a specific species of misfolded procollagen and plays a protective role in cell survival against ER stress. Autophagy 5:1217-1219.

Jia LY, Gong B, Pang CP, Huang Y, Lam DS, Wang N, Yam GH (2009) Correction of the disease phenotype of myocilin-causing glaucoma by a natural osmolyte. Invest Ophthalmol Vis Sci 50(8):3743-3749.

Kapoor A, Sanyal AJ (2009) Endoplasmic reticulum stress and the unfolded protein response. Clin Liver Dis 13(4):581-590.

Kars M, Yang L, Gregor MF, Mohammed BS, Pietka TA, Finck BN, Patterson BW, Horton JD, Mittendorfer B, Hotamisligil GS, Klein S (2010) Tauroursodeoxycholic acid may improve liver and muscle but not adipose tissue insulin sensitivity in obese men and women. Diabetes 59(8):1899-1905.

Kawasaki N, Asada R, Saito A, Kanemoto S, Imaizumi K (2012) Obesity-induced endoplasmic reticulum stress causes chronic inflammation in adipose tissue. Sci Rep 2(799):1-7.

Kim JA, Jang HJ, Hwang DH (2015) Toll-like receptor 4-induced endoplasmic reticulum stress contributes to impairment of vasodilator action of insulin. Am J Physiol Endocrinol Metab 309(9):E767-E776.

Koracevic D, Koracevic G, Djordjevic AS, Cosic V (2001) Method for measurement of antioxidant activity $V$ in human fluids. J Clin Pathol 54(5):339.

Laemmli UK (1970) Cleavage of structural proteins during the assembly of the head of bacteriophage T4. Nature 227:680-685.

Lipson KL, Fonseca SG, Ishigaki S, Nguyen LX, Foss E, Bortell R, Rossini AA, Urano F (2006) Regulation of insulin biosynthesis in pancreatic beta cells by an endoplasmic reticulum-resident protein kinase IRE1. Cell Metab 4:245-254.

Lowry OH, Rosebrough NJ, Farr AL, Randall RJ (1951) Protein measurement with the folin phenol reagent. J Biol Chem 193:265-275.

Lupachyk S, Watcho P, Stavniichuk R, Shevalye H, Obrosova IG (2013) Endoplasmic reticulum stress plays a key role in the pathogenesis of diabetic peripheral neuropathy. Diabetes 62(3):944-952.

Matthews DR, Hosker JP, Rudenski AS, Naylor BA, Treacher DF, Turner RC (1985) Homeostasis model assessment: insulin resistance and beta-cell function from fasting plasma glucose and insulin concentrations in man. Diabetologia 28(7):412-419. 
Mulhern ML, Madson CJ, Kador PF, Randazzo J, Shinohara T (2007) Cellular osmolytes reduce lens epithelial cell death and alleviate cataract formation in galactosemic rats. Mol Vis 13:1397-1405.

Nakagawa T, Zhu H, Morishima N, Li E, Xu J, Yuan J (2000) Caspase-12 mediates endoplasmic-reticulum-specific apoptosis and cytotoxicity in amyloid-beta. Nature 403:98-103.

Ohkawa H, Ohishi N, Yagi K (1979) Assay for lipid peroxides in animal tissues by thiobarbituric acid reaction. Anal Biochem 95(2):351-358.

Oikawa D, Kimata Y, Kohno K (2007) Self-association and BiP dissociation are not sufficient for activation of the ER stress sensor Ire1. J Cell Sci 120:1681-1688.

Ozcan U, Cao Q, Yilmaz E, Lee AH, Iwakoshi NN, Ozdelen E, Tuncman G, Gorgun C, Glimcher LH, Hotamisligil GS (2004) Endoplasmic reticulum stress links obesity, insulin action, and type 2 diabetes. Science 306:457-461.

Ozcan U, Yilmaz E, Ozcan L, Furuhashi M, Vaillancourt E, Smith RO, Görgün CZ, Hotamisligil GS (2006) Chemical chaperones reduce ER stress and restore glucose homeostasis in a mouse model of type 2 diabetes. Science 313(25):1137-1140.

Paik DC, Dillon J (2000) The nitrite/alpha crystallin reaction: a possible mechanism in lens matrix damage. Exp Eye Res 70(1):73-80.

Pollreisz A, Schmidt-Erfurth U (2010) Diabetic cataract-pathogenesis, epidemiology and treatment. J Ophthalmol 608751:1-8.

Rajan SS, Srinivasan V, Balasubramanyam M, Tatu U (2007) Endoplasmic reticulum (ER) stress and diabetes. Indian J Med Res 125:411-424.

Ransom M, Dennehey BK, Tyler JK (2010) Chaperoning histones during DNA replication and repair. Cell 140:183-195.

Sambrook J, Fritschi EF, Maniatis T (1989) Molecular cloning: a laboratory manual. Cold Spring Harbor Laboratory Press, New York.

Song S, Liang JJ, Mulhern ML, Madson CJ, Shinohara T (2011) Cholesterol-derived bile acids enhance the chaperone activity of a-crystallins. Cell Stress Chaperones 16(5):475-480.

Srinivasan K, Patole PS, Kaul CL, Ramarao P (2004) Reversal of glucose intolerance by pioglitazone in high-fat diet fed rats. Methods Find Exp Clin Pharmacol 26:327-333.

Srinivasan K, Viswanad B, Asrat L, Kaul CL, Ramarao P (2005) Combination of high-fat diet-fed and low-dose streptozotocin-treated rat: a model for type 2 diabetes and pharmacological screening. Pharmacol Res 52:313-320.

Suryanarayana P, Krishaswamy K, Reddy GB (2003) Effect of curcumin on galactose-induced cataractogensis in rats. Mol Vis 9:223-230.

Szkudelski T (2001) The mechanism of alloxan and streptozotocin action in B cells of rat pancreas. Physiol Res 50(6):537-546.

Towbin H, Staehelin T, Gordon J (1979) Electrophoretic transfer of proteins from polyacrylamide gels to nitrocellulose sheets: procedure and some applications. Proc Natl Acad Sci U S A 76:4350-4354.

Trinder P (1969) Determination of glucose by colorimetric method. Ann Clin Biochem 6:24-33.

Ullman E, Fan Y, Stawowczyk M, Chen HM, Yue Z, Zong WX (2008) Autophagy promotes necrosis in apoptosis-deficient cells in response to ER stress. Cell Death Differ 15(2):422-425.

Urano F, Wang X, Bertolotti A, Zhang Y, Chung P, Ron D (2000) Coupling of stress in the ER to activation of JNK protein kinases by transmembrane protein kinase IRE1. Science 287:664-666.

Vang S, Longley K, Steer CJ, Low WC (2014) The unexpected uses of urso- and tauroursodeoxycholic acid in the treatment of non-liver diseases. Glob Adv Health Med 3(3):58-69.

Walter $P$, Johnson AE (1994) Signal sequence recognition and protein targeting to the endoplasmic reticulum membrane. Ann Rev Cell Biol 10:87-119.

Welch WJ, Brown CR (1996) Influence of molecular and chemical chaperones on protein folding. Cell Stress Chaperones 1:109-115.

Xu GT, Zigler JS Jr, Lou MF (1992) The possible mechanism of naphthalene cataract in rat and its prevention by an aldose reductase inhibitor (alo1576). Exp Eye Res 54:63-72.

Yung HW, Alnæs-Katjavivi P, Jones CJ, El-Bacha T, Golic M, Staff AC, Burton GJ (2016) Placental endoplasmic reticulum stress in gestational diabetes: the potential for therapeutic intervention with chemical chaperones and antioxidants. Diabetologia 59(10):2240-2250.

Zhang J, Fan Y, Zeng C, He L, Wang N (2016) Tauroursodeoxycholic acid attenuates renal tubular injury in a mouse model of type 2 diabetes. Nutrients 8(10):1-11.

Zinszner H, Kuroda M, Wang X, Batchvarova N, Lightfoot RT, Remotti H, Stevens JL, Ron D (1998) CHOP is implicated in programmed cell death in response to impaired function of the endoplasmic reticulum. Genes Dev 12(7):982-995.

\section{Submit your manuscript to a SpringerOpen ${ }^{\circ}$ journal and benefit from:}

- Convenient online submission

- Rigorous peer review

- Open access: articles freely available online

High visibility within the field

- Retaining the copyright to your article

Submit your next manuscript at $>$ springeropen.com 